\title{
Investigating the Relationship of Gifted Students' Perceptions Regarding Science Learning Environment and Motivation for Science Learning with their Intellectual Risk Taking and Science Achievement
}

\author{
Emine Akdağ'1, Mustafa Serdar Köksal2* \\ 'Department of Educational Sciences, Inonu University, Malatya, Turkey, ${ }^{2}$ Department of Special Education, Faculty of Education, Gifted Education, \\ Hacettepe University, Ankara, Turkey
}

*Corresponding Author: bioeducator@gmail.com

\section{ABSTRACT}

The purpose of this research was to examine relationship between the eighth-grade gifted students' perceptions of science learning environment constructive learning environment perception (CLEP) and their motivations motivation to learn science (MLS) to learn science with their intellectual risk-taking (IRT) and science achievement (SA). For this purpose, the predictive research method was chosen. The sample consisted of $1338^{\text {th }}$ grade gifted students in Science and Art Centers in nine provinces of Turkey. The data collection instruments involved "IRT Scale," "Motivational Strategies for Learning Questionnaire," "Constructivist Learning Environment Scale," and "SA Test." In the research, path analysis was used to determine causal relationships between these variables. As a result of the analyzes, it was determined that CLEP predicted IRT and SA, MLS significantly predicted IRT in learning science and SA and IRT in learning science predicted SA. The findings were discussed by considering their importance for teaching and learning science in gifted education context.

KEY WORDS: gifted students; motivation for science learning; intellectual risk taking in learning science; constructivist science learning environment; science achievement

\section{INTRODUCTION}

$\mathbf{T}$ he positive association between countries' scientific and technological knowledge and their level of development is a well-known fact. Although all individuals have an important potential for their society, this knowledge that will lead a society to a high civilization level is only possible by individuals who are able to execute high-level cognitive functioning, who can realize and offer various explanations for solving problems, and who can excel in different fields. Watters and Diezmann (2003) stated that people with special talent have a great role in the development of countries. In the Special Education Services Regulation (MONE, 2016), the concept of special talent is considered together with giftedness and an individual with special talent or gifted individual - is defined as "an individual who performs at a higher level than his/her peers in intelligence, creativity, art, sports, leadership, or special academic fields" (MONE, 2016, p. 2). Similarly, Hoh (2008) and Davis and Rimm (2004) consider gifted individuals who are noticeable in the society in terms of cognitive, affective, and psychomotor learning domains as individuals who can display superior analytical skills and have high-level thinking skills such as abstract, logical, creative, and critical thinking. These characteristics point to requirement of challenging and enriched teaching in gifted education.

The fact that science is a challenging field that contains abstract and complex elements is a critical feature that causes science to attract highly gifted individuals' attention (Tomlinson, 2005). Moreover, science contributes to practical skills and includes activities that require the use of mind and hands, which make this area more attractive for gifted individuals (Morris et al., 2019). The nature of science requires making generalizations with the help of predictions using scientific data to provide an enriched and openended learning process, which is a necessity for educating gifted individuals. The reflection of these processes on formal science education is a desirable circumstance for those individuals' education. The ability to provide rich, open-ended, and challenging learning processes in science courses is related to how much intellectual risk is allowed in the teaching environment, how positive the learning environment perception is, and how much motivational support is provided (Beghetto, 2009; Glynn et al., 2005; Marlowe and Page, 2005). Therefore, this study aimed to examine the associations among constructive learning environment perception (CLEP), motivation to learn science 
(MLS), intellectual risk-taking (IRT) behaviors, and science achievement (SA) of eighth-grade gifted students.

\section{Literature Review}

\section{IRT and science education}

The main objectives of science education worldwide include teaching higher-order thinking skills such as understanding scientific knowledge, problem solving, critical thinking, and creative thinking (MONE, 2017). To achieve these goals, students need to be encouraged to choose difficult tasks in learning environment as a result of taking intellectual risks and work in a task-oriented way. Beghetto (2009) defines IRT behavior as the willingness to share ideas about a subject, ask questions, and try new and alternative ways to solve a problem, even if one is not sure. Individuals who take intellectual risks have the ability to evaluate the possible consequences of participating in a learning action and decide to participate in it (Robinson and Bell, 2012). Students with high levels of IRT may display behaviors including sharing their ideas in the classroom, asking questions to their friends or teachers, making explanations about a topic discussed in the classroom, offering solutions to a problem that has not been tried before, and being able to use the previously learned knowledge in new activities (Beghetto, 2009; House, 2002; Neihart, 1999). Specifically, gifted individuals have a very high potential in showing many behaviors related to IRT (Akdağ and Köksal, 2017). Rainwater and Wittner (2016) stated that gifted students' high success in cognitive areas including SA, understanding, and problem solving is a result of their IRT behaviors. In addition, Soares (2016) stated that gifted students focus on questioning the phenomenon related to a scientific problem within the scope of IRT rather than focusing on a single solution to solve the problem.

Çakır and Yaman (2015) found that IRT skills and cognitive awareness levels of ordinary students were higher than average and there was a positive significant relationship between IRT skills, metacognitive awareness levels, and SA. Similar results were found for ordinary students by Özbay (2016). On the other hand, Akdağ and Köksal (2017) compared gifted students with the others in terms of IRT skills and found no difference between them. In another study, Daşc1 and Yaman (2014) examined the change in IRT skills of gifted students with time. The results revealed that students' skills decreased as their grade levels got higher. The researchers specifically found that by eight grade there is a straight decrease in students' IRT skills. Akdağ et al. (2016) found a similar result for gifted students. These two studies may be considered as evidence of the need to examine the variables that might be related to the decrease in students' IRT skills. In another study, Akkaya (2016) attempted to increase fourth grade students' IRT skills through animations. According to the results, animations were found to be effective in increasing their skills as well as their achievement in science. Gifted students tend to be successful in science due to their IRT skills. More specifically, IRT skills predict students' achievement in science (Beghetto, 2009). However, there exist a limited number of studies focusing on relationship of this variable with other important variables in science education. Therefore, examining the association between IRT behavior and other critical variables is critical to provide enriched learning processes for gifted students.

\section{Motivation in science learning}

Students' ability to take intellectual risks to a certain extent is effective in increasing their motivation and SA (Beghetto, 2009; House, 2002). Pintrich (2003) defines motivation as a structure that includes intrinsic or extrinsic factors that affect the stimulation, maintenance, and control of a behavior. In addition, motivation is the most critical factor that affects SA of students who continues learning activities and that ensures the continuation of their success (Glynn et al., 2005; Guay et al., 2010; Martin, 2001; Pintrich, 2003; Schulze and Lemmer, 2017). Matthews and McBee (2007) also reveal that one of the main reasons in academic failure is lack of motivation, especially for gifted students. The motivation of a gifted student is a complex structure that is affected by content, materials, curriculum, teaching methods, and teacher's and student's personal characteristics (Lee and Brophy, 1996). In other words, the motivation of those individuals while learning science is influenced by IRT behaviors and key components of teaching (Lee and Brophy, 1996; Matthews and McBee, 2007).

There are studies focusing on gifted students and their MLS. Kanlı and Emir (2009) designed a science program for gifted students and examined its effectiveness and its effect on students' motivation. The results showed that the program positively affected gifted students' motivation. Alkan and Bayri (2017) reported that many studies found evidence showing the positive association between students' motivation and SA. However, in a study, Köksal (2013b) examined the association between motivation and students' IQ level, logical thinking, and critical thinking and found no association between students' motivation and the other variables. This revealed that there was an important gap between motivation and cognitive learning in terms of gifted students. Therefore, it is critical to examine the association between MLS and IRT skills and their effects on SA to plan enriched science curriculum and teaching for gifted students.

\section{Learning environment in science education}

Learning environment is another factor that affects students' MLS and IRT behaviors (Nickerson, 1999; Y1lmaz and Cavas, 2007). Active learning environments in which students are encouraged to use the skills and processes related to inquiry in science learning and to search about their own thoughts positively affect students' MLS (Lang et al., 2005; Velayutham et al., 2012; Watters and Diezmann, 2003). Learning environments where scientific inquiries and research are carried out and problems are solved by using higher order thinking skills are constructive learning environments (Marlowe and Page, 2005). Students in these learning environments may easily share their comments or guesses with the others by thinking deeply about a problem even if they cannot predict the results in the solution of the problem. 
These behaviors constitute the content of IRT, which indicates a relationship between IRT and CLEP as Nickerson (1990) stated. Rita and Martin-Dunlop (2011) examined students' preferences in terms of learning environment and found that students preferred a more constructive learning environment than the one they were actually experiencing. In addition, the researchers revealed the positive and significant association between students' academic achievement and CLEP. Similar results were found in another study conducted by Pramathevan and Fraser (2019). Moreover, CLEP has a significant effect in supporting students' motivation for learning (Yllmaz and Çavaş, 2007). However, students' general perspectives reveal that this environment are not well-established in schools of Turkey (Baş, 2012), which requires more research to fill the gap in the literature. In these schools, gifted students are also taking courses, but there is no study focusing on the association of their learning environment with motivation and IRT.

Based on the literature, it is concluded that the IRT, MLS, and CLEP variables are effective in increasing the classroom activities of gifted students and the quality of the teaching process. Therefore, it is critical to determine the association among those variables. The findings of this study will provide an evidence-based outline for enriched classroom activities.

\section{METHODOLOGY}

In this study, a correlational research approach was employed in order to examine the association among variables and to predict possible results. To provide a better understanding of the source of variation in the data set, a path analysis, a special technique of multiple regression analysis, was performed in the study (Daşdağ et al., 2006). Based on the literature review, a model was designed to represent the possible associations among the variables and is depicted in Figure 1.

In the path diagram, causal relationships between variables are shown with one-way arrows. Accordingly, when Figure 1 is examined, it is seen that the CLEP and MLS variables are direct and indirect predictors of the IRT variable and all these variables together are predictors of SA in science. In addition, since CLEP and MLS are related to each other, this association is expressed by a two-way arrow. In the path analysis technique, explanatory and predictive correlations between variables form a complex structure. Therefore, instead of separating variables as dependent and independent variables in path diagrams, predicted variables are generally classified as endogenous variables and predictive variables as exogenous

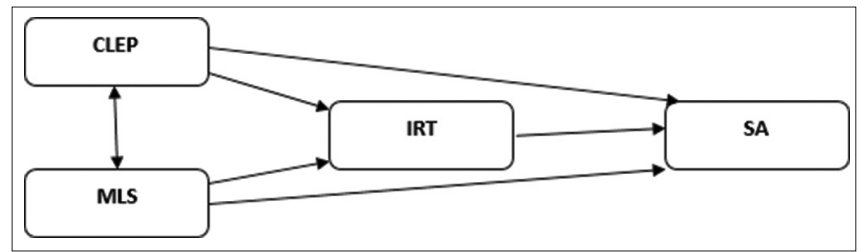

Figure 1: Initial hypothesized model for the relationship among science constructive learning environment perception, motivation to learn science, intellectual risk-taking, and academic achievement variables (Bayram, 2013). As seen from the figure, CLEP and MLS are the exogenous variables of the hypothesis and IRT and SA are endogenous variables.

\section{Participants}

Participants of the current study were students of the Science and Art Centers (SAC). SAC are institutions that provide after-school programs for gifted students. Students need to pass two different stages of identification to be admitted to the program. The stages are prepared to identify gifted students and the students should have IQ scores higher than cutoff determined by the ministry. Students who are enrolled in SAC complete the following sessions throughout the academic year: Adaptation, support training, realization of individual abilities, development of special skills, and project training and management (MONE, 2016). There is an obligation to attend all sessions and students who complete the program are provided a certificate of completion.

The population of the study consists of eight-grade gifted students (Mean age $=14$ ) in Turkey. Geographically, Turkey is divided into seven regions. For this particular study, one big city and one small city were identified from each region, which makes 14 cities in total. Those cities are Malatya, Elazığ, Gaziantep, Adıyaman, Adana, Osmaniye, İzmir, Afyon, Bursa, Bilecik, Samsun, Tokat, Sivas, and Ankara. There is at least one SAC in each city. Before conducting the study, necessary permissions were obtained from the Ministry of Education. Moreover, informed consent forms were also signed by the parents of the participants. The participants of the study consist of the SAC students $(n=132$, females $=46$ and males $=86)$ from those cities. A total of 133 students were recruited for the study. Due to missing values and invariance, one case was dropped out from the path analysis, which left 132 cases. Sample size is critical for validity and reliability of analysis.

\section{Data Collection Tools}

In this study, five different data collection tools were used: A demographic information form, the IRT in science scale (IRT-S), constructive learning environment scale, motivational strategies learning questionnaire, and an academic achievement test. The demographic information form included questions related to gender, age, grade level, and the SAC location the participants registered. The details of the other data collection tools are provided below.

\section{The IRT-S}

The scale was developed by Beghetto (2009) and adopted to Turkish by Yaman and Köksal (2014). It has six items under only one factor. Each item was measured with a five-point Likert type and responses ranged from not true (1) to very true (5). There was no reverse-coded item in the scale. An example item is "During science, I like doing new things even if I am not very good at them." The good fit and acceptable fit indices (Büyüköztürk et al., 2016; İlhan and Çetin, 2014) and the fit indices calculated for the scale with one-factor in this study are provided in Table 1. 
According to the results, while $\mathrm{x}^{2} / \mathrm{df}$ value (1.764) was considered as good fit, the comparative fit index CFI (0.88) and goodness of fit index (GFI) values (0.95) were at acceptable level. The Cronbach's alpha value was calculated as 0.68 .

\section{The Constructivist Learning Environments Scale (CLES)}

The scale developed by Taylor and Fraser (1991) aims to measure students' perceptions related to the frequency of occurrence of critical constructive learning environment. Although the original scale had 30 items, it was revised by Johnson and McClure (2004) and reduced to 20 items. The items in the revised version of the scale were designed as a five-point Likert type ranged from never (1) to always (5). The scale has five factors including personal relevance, uncertainty, critical voice, shared control, and student negotiation. The Cronbach's alpha coefficient was calculated as 0.91. An example item is "Students talk with other students about how to solve problems." The fit indices obtained from the confirmatory factor analysis in this study, good and acceptable fit indices are provided in Table 2.

According to the table, $\mathrm{x}^{2} / \mathrm{df}(1.15)$ and CFI (0.96) were at acceptable level. Although, GFI value was not among the acceptable values in Table 2, they were close to this level based on a study conducted by Büyüköztürk et al. (2004). Hence, we ignored the GFI value due to the importance of the variable in the study.

\section{The Motivational Strategies for Learning Questionnaire (MSLQ)}

To examine students' motivational level in science courses, the MSLQ was used. The questionnaire was developed by Pintrich et al. (1991) and translated to Turkish by Sungur (2004). It consisted of two sections: motivation (31 items) and learning strategies (51 items). An example item is "It is important for me to learn scientific concepts." For this particular study, only four sub-dimensions of the motivation section were used: Intrinsic goal orientation, task value, control of learning beliefs,

$\begin{aligned} & \text { Table 1: The fit index values for the scale based on the } \\
& \text { confirmatory factor analysis }\end{aligned}$
\begin{tabular}{lccc} 
Fit & Good fit & Acceptable \\
indexes & values & values & $\begin{array}{c}\text { One-factor } \\
\text { structure values }\end{array}$ \\
\hline $\mathrm{x}^{2} / \mathrm{df}$ & $0 \leq \mathrm{x}^{2} / \mathrm{d} \leq 2$ & $2 \leq \mathrm{x}^{2} / \mathrm{df} \leq 3$ & 1.764 \\
$\mathrm{CFI}$ & $0.97 \leq \mathrm{CFI} \leq 1$ & $0.80 \leq \mathrm{CFI} \leq 0.97$ & 0.88 \\
GFI & $0.95 \leq \mathrm{GFI} \leq 1$ & $0.90 \leq \mathrm{GFI} \leq 0.95$ & 0.95 \\
\hline
\end{tabular}

GFI: Goodness of fit index, CFI: Comparative fit index

Table 2: The fit index values for the scale based on the confirmatory factor analysis

\begin{tabular}{lccc}
\hline $\begin{array}{l}\text { Fit } \\
\text { Indexes }\end{array}$ & $\begin{array}{c}\text { Good fit } \\
\text { values }\end{array}$ & $\begin{array}{c}\text { Acceptable } \\
\text { values }\end{array}$ & $\begin{array}{c}\text { Five-factor } \\
\text { structure values }\end{array}$ \\
\hline $\mathrm{x}^{2} / \mathrm{df}$ & $0 \leq \mathrm{x}^{2} / \mathrm{df} \leq 2$ & $2 \leq \mathrm{x}^{2} / \mathrm{df} \leq 3$ & 1.15 \\
$\mathrm{CFI}$ & $0.97 \leq \mathrm{CFI} \leq 1$ & $0.95 \leq \mathrm{CFI} \leq 0.97$ & 0.96 \\
$\mathrm{GFI}$ & $0.95 \leq \mathrm{GFI} \leq 1$ & $0.90 \leq \mathrm{GFI} \leq 0.95$ & 0.78 \\
\hline
\end{tabular}

GFI: Goodness of fit index, CFI: Comparative fit index and self-efficacy for learning and performance. In this study, only intrinsic goal orientation was used to measure motivation toward learning science. By this way, we reduced number of questions applied to the student. The Cronbach's alpha coefficient was calculated as 0.83 . The fit indices obtained from the confirmatory factor analysis; in this study, good and acceptable fit indices are provided in Table 3.

The table presents the good and acceptable fit indices (IIlhan and Çetin, 2014) and the fit indices of the scale. The values for $\mathrm{x}^{2} / \mathrm{df}$, CFI, and GFI were at the good fit range. Therefore, the scale perfectly fits the previously determined one-factor structure.

\section{Academic Achievement Test for Science (AAT-S)}

Another data collection tool is the AAT-S, which is a 45-item test developed by Aşut (2013). The items in the test were designed by taking into account the $6^{\text {th }}, 7^{\text {th }}$, and $8^{\text {th }}$ grade science curriculum. The descriptive results are presented in Table 4.

The reliability level of the test was determined based on the KR-20 internal consistency coefficient, which was found to be 0.81 . This value is an acceptable value according to Esin (2014). The average item difficulty index (0.64) and average discrimination index (0.33) values revealed that the test is at medium difficulty level (Pehlivan-Tunç and Kutlu, 2014). An example item is provided below.

Question: Which of the following is not included in the "productive livings" category?
a. Human
b. Sunflower
c. Cyanobacteria
d. Blue-green algae.

$\begin{aligned} & \text { Table 3: The fit index values for the scale based on the } \\
& \text { confirmatory factor analysis }\end{aligned}$
\begin{tabular}{lccc} 
Fit & Good fit & Acceptable \\
Indexes & values & values & $\begin{array}{c}\text { One-factor } \\
\text { structure values }\end{array}$ \\
\hline $\mathrm{x}^{2} / \mathrm{df}$ & $0 \leq \mathrm{x}^{2} / \mathrm{d} \leq 2$ & $2 \leq \mathrm{x}^{2} / \mathrm{d} \leq 3$ & 0.6 \\
$\mathrm{CFI}$ & $0.97 \leq \mathrm{CFI} \leq 1$ & $0.95 \leq \mathrm{CFI} \leq 0.97$ & 0.99 \\
GFI & $0.95 \leq \mathrm{GFI} \leq 1$ & $0.90 \leq \mathrm{GFI} \leq 0.95$ & 0.99 \\
\hline
\end{tabular}

GFI: Goodness of fit index, CFI: Comparative fit index

Table 4: Descriptive statistics and item analysis results of the test

\begin{tabular}{lc}
\hline Statistics & Values \\
\hline Number of items & 45 \\
Number of participants & 63 \\
Average Score & 29.25 \\
Standard Deviation & 6.39 \\
Variance & 40.87 \\
Minimum score & 12 \\
Maximum score & 39 \\
Average difficulty index & 0.64 \\
Average discrimination index & 0.33 \\
KR-20 (Alpha) Reliability & 0.81 \\
\hline
\end{tabular}




\section{Data Analysis}

To reveal the causal relationships between variables, a path analysis was conducted. Before the path analysis, validity and reliability analyses were conducted for each data collection tool and the results were provided above. Then, average scores were calculated for each of them and screened to determine whether the data were normally distributed. According to the Skewness and kurtosis values, the data were normally distributed. Therefore, parametric tests were run for analysis.

Before testing the initial model, the direction and degree of relationships between variables were determined using Pearson product-moment correlation coefficients. In addition, multivariate normality was examined by calculating Mardia (1970) multivariate kurtosis coefficient values. The result revealed that the data were suitable for the path analysis. The IBM SPSS AMOS version 21 was used to calculate the path coefficients. The direct, indirect, and total effects of the variables on each other were determined with the calculated path coefficients. The compatibility of the initial model with the data was examined by calculating the fit indices. The differences between the expected and observed data matrices were examined and the concordance between matrices was revealed. The results are provided below.

\section{Findings}

The findings of the study are discussed under two sub-headings as descriptive findings and inferential findings.

\section{Descriptive findings}

The descriptive results related to IRT-S, CLES, MSLQ, and AAT-S of eight grade-gifted students are provided in Table 5.

According to the findings, students had above average score for AAT-S, IRT-S, CLES, and MSLQ. The skewness values ranged between -0.96 and 0.12 and the kurtosis values ranged between 0.167 and 2.4. These values revealed that the data were normally distributed (Tabachnick and Fidell, 2013).

\section{INFERENTIAL RESULTS}

To identify the direct and indirect effect of SA, IRT, CLEP, and MLS path analysis was performed. Before discussing the path analysis results, it is critical to examine the one-way correlations among those variables. Table 6 provides the correlation matrix of all the factors.

According to the matrix, significant correlations were found between CLEP and MLS, CLEP and IRT, MLS and IRT, and IRT and SA. Among them, the one between IRT and SA was negative. There was no correlation between CLEP and SA and MLS and SA. The descriptive findings and the correlation matrix values revealed that the data were suitable for path analysis except for the association between CLEP and SA. The hypothesized model is provided in Figure 2.

Figure 2, it is seen that MLS and CLEP directly influence IRT, and IRT directly influence SA. In addition, MLS and CLEP indirectly influence SA through IRT. CLEP and MLS are the exogenous variables of the model, IRT and SA are the endogenous variables. In this model presented in Figure 2, the variables in the rectangle area are the observed variables of the model; therefore, each has a standardized error term (e1, e2, e3, and e4), which are represented in the model with a one-way arrow as the exogenous unobserved variable. To test the model, path analysis was performed and the results are provided in Figure 3.

Table 5: Descriptive results

\begin{tabular}{lcccc}
\hline \multirow{2}{*}{ Values } & \multicolumn{4}{c}{ Tools } \\
\cline { 2 - 5 } & AAT-S & IRT-S & CLEP & MSLQ \\
\hline Number of participants & 132 & 132 & 132 & 132 \\
Mean & $30.06 / 45$ & $3.74 / 5$ & $3.66 / 5$ & $4.28 / 6$ \\
Standard deviation & 5.8 & 0.74 & 0.65 & 0.51 \\
Minimum & 13 & 1.2 & 1.00 & 1.00 \\
Maximum & 39 & 5.00 & 4.80 & 6.4 \\
Skewness & -0.78 & -0.96 & -0.71 & 0.11 \\
Standard error for skewness & -4.52 & -3.33 & 0.55 & -3.67 \\
Kurtosis & 0.16 & 1.2 & 1.4 & 2.4 \\
Standard error for kurtosis & 0.39 & 2.81 & 3.27 & 5.81
\end{tabular}

AAT-S: Academic achievement test for science, IRT-S: Intellectual risk-taking in science scale, CLEP: Constructive learning environment perception, MSLQ: Motivational strategies for learning questionnaire

\begin{tabular}{|c|c|c|c|c|}
\hline Variables & CLEP & MLS & IRT & SA \\
\hline CLEP & - & & & \\
\hline MLS & $0.33 *$ & - & & \\
\hline IRT & $0.57 *$ & $0.29 *$ & - & \\
\hline AA & 0.01 & 0.02 & $-0.04 *$ & - \\
\hline
\end{tabular}

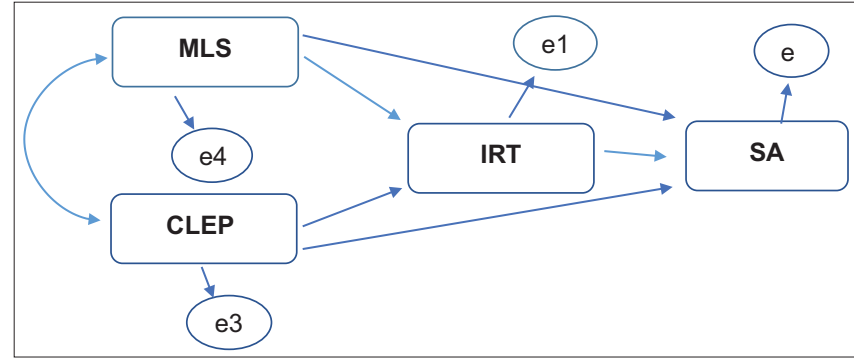

Figure 2: The hypothesized model

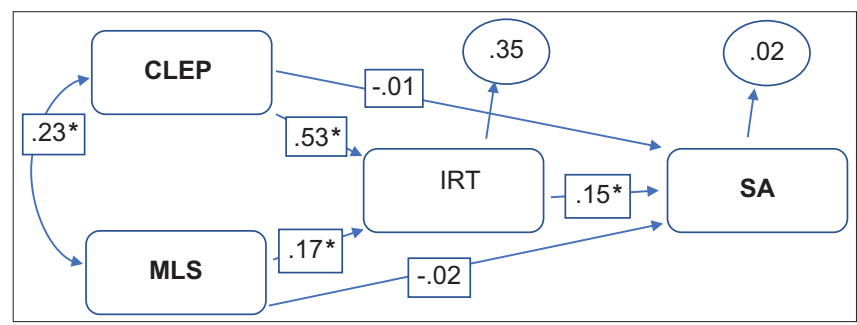

Figure 3: Path analysis results $\left({ }^{*}<0.05\right)$ 
According to Suhr (2008), inter-variable path coefficients are divided into three categories: small effect if path coefficients $<0.1$, medium effect if between 0.0.1 and 0.5, and large effect if $>0.5$. According to Figure 3 , there was a large effect between CLEP and IRT $(\beta=0.53)$, a medium effect between MLS and IRT ( $\beta=0.17)$, IRT and SA ( $\beta=0.15)$, and CLEP and MLS $(\beta=0.23)$, and a small effect between CLEP and SA $(\beta=-0.01)$ and MLS and SA $(\beta=-0.02)$. In addition, the fit indices of the model were not acceptable. To improve the model fit, the model was modified by removing the paths between CLEP and SA and MLS and SA (Figure 4).

According to the modified model, although CLEP and MLS did not directly influence SA, they indirectly influenced it through IRT. Furthermore, IRT directly influenced SA, which revealed the association between them. There was a correlation between CLEP and MLS. In order to test the model, fit indices $\left(\chi^{2} / \mathrm{df}\right.$ ratio, GFI, root-mean-square error of approximation [RMSEA], adjusted goodness-of-fit index [AGFI], and CFI) need to be calculated through path analysis (Bentler and Yuan, 1999; Pedhazur, 1997). The good and acceptable fit indices and the fit indices of the model are provided in Table 7 (Baumgartner and Homburg, 1996; Byrne, 2010; Kline, 2011; Meyers et al., 2016; Schermelleh-Engel and Moosbrugger, $2003)$. The $\chi^{2} / \mathrm{df}$ ratio of the modified model (0.04) was among the good fit criteria.

Accordingly, there was no significant difference between the observed covariance matrix and the estimated covariance matrix; therefore, the model was found to be fit. Another fit index value in Table 7 is the GFI and it shows to what extent the developed model measures the covariance matrix of the sample (Çokluk et al., 2012). The value above 0.95 proves the perfect fit of the model. The GFI value for the modified model was calculated as 0.99 , which shows that the model was the

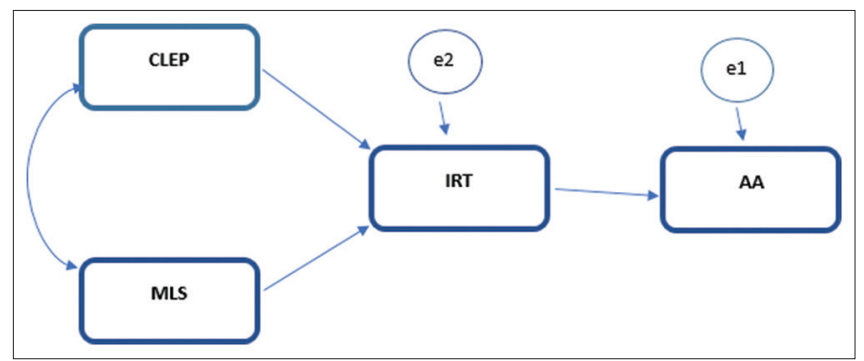

Figure 4: The modified model

\begin{tabular}{lccc}
\hline \multicolumn{4}{l}{ Table 7: Fit index values for the modified model } \\
\hline $\begin{array}{l}\text { Fit } \\
\text { Indexes }\end{array}$ & Good fit & Acceptable & $\begin{array}{c}\text { Modified fit } \\
\text { indices }\end{array}$ \\
\hline$\chi^{2} / \mathrm{SD}$ & $0 \leq \chi^{2} / \mathrm{SD} \leq 2$ & $2 \leq \chi^{2} / \mathrm{SD} \leq 3$ & 0.04 \\
$\mathrm{AGFI}$ & $0.90 \leq \mathrm{AGFI} \leq 1.00$ & $0.85 \leq \mathrm{AGFI} \leq 0.90$ & 0.99 \\
$\mathrm{GFI}$ & $0.95 \leq \mathrm{GFI} \leq 1.00$ & $0.90 \leq \mathrm{GFI} \leq 0.95$ & 0.99 \\
$\mathrm{CFI}$ & $0.95 \leq \mathrm{CFI} \leq 1.00$ & $0.90 \leq \mathrm{CFI} \leq 0.95$ & 0.99 \\
$\mathrm{RMSEA}$ & $0.00 \leq \mathrm{RMSEA} \leq 0.05$ & $0.05 \leq \mathrm{RMSEA} \leq 0.08$ & 0.00 \\
\hline
\end{tabular}

GFI: Goodness of fit index, CFI: Comparative fit index, AGFI: Adjusted goodness-of-fit index, RMSEA: Root-mean-square error of approximation perfect fit. Furthermore, the adjusted GFI was found to be 0.99 , which is in the perfect fit range. The CFI examines the model fit by examining the disagreement between the data and the hypothesized model (Çokluk et al., 2012). According to the table, the CFI value verified that the model was perfect fit. The RMSEA value compares the observed covariance matrix with the hypothesized covariance matrix. Unlike GFI and AGFI, this value is expected to be close to zero with the $90 \%$ confidence interval (Schumacker and Lomax, 2010). According to the findings, the RMSEA value of 0.00 verified the perfect fit.

According to the findings, the modified model fit perfectly with the data. However, it is critical to examine the direct and indirect effects among variables. These relationships between variables were addressed based on the path coefficients and variance rates. The path coefficient values are given in Figure 5.

According to the results provided in Figure 5, the explanatory relationships between variables were at a significant level $(<0.05)$. In other words, a cause-effect relationship was established between variables. The path coefficient values between the variables and the explained variance ratios were $\beta=0.39, R^{2}=0.15$ between CLEP and MLS, $\beta=0.53$, $\mathrm{R}^{2}=0.28$ between CLEP and IRT, $\beta=0.17, \mathrm{R}^{2}=0.02$ between MLS and IRT, and $\beta=0.14, \mathrm{R}^{2}=0.01$ between IRT and SA.

The path coefficient value between CLEP and MLS was 0.39 $(<0.05$ and $t=2.5)$, which shows a linear relationship between the variables. In other words, students with a high perception of science learning environment had high intrinsic MLS.

The path coefficient value between CLEP and IRT was 0.53 $(<0.05$ and $t=7.35)$. One unit of change in the standard deviation of CLEP directly created a change of 0.53 in the standard deviation of IRT. According to Suhr (2008), there was a high correlation between the CLEP and IRT. As a result, students who had positive perception about constructive learning environments tended to take intellectual risks while learning science.

The path coefficient value between MLS and IRT was 0.17 $(<0.05$ and $t=2.3)$. MLS directly created a change of 0.17 in the standard deviation of IRT, which shows a medium level association between these two variables (Suhr, 2008). This result reveals that students with high level of intrinsic motivation took a moderate level of intellectual risks in science lessons.

The path coefficient value between IRT and SA was 0.14 $(<0.05$ and $t=1.6)$. IRT created a change of 0.14 in the standard deviation of IRT. Suhr (2008) considers this change as a medium level association. This result may be interpreted that IRT behavior in science lessons affects students' SA in science at a moderate level.

One of the advantages of path analysis compared with the other regression analysis is that path analysis provides information about both direct and indirect effects among variables. 
This advantage enables researchers to compare the direct and indirect effects and to find overall effect (Asher, 1983; Olobatuyi, 1992). As discussed previously, the path coefficients in the model are the direct effects. On the other hand, indirect effect is the effect level of the external or internal explanatory variable on the variable explained through another variable. The indirect effect value is calculated as the multiplication of a path coefficient between the explanatory variable and the mediating variable with a path coefficient between the mediating variable and the explained variable. The overall effect of the explanatory variable on the explained variable is the sum of the direct and indirect effects (Çokluk et al., 2012). The direct, indirect, and overall effects of the variables in the model are provided in Table 8 .

According to the table, CLEP had an indirect effect (0.07) on SA through IRT. In other words, one unit change in the standard deviation of CLEP creates a change of 0.07 in the standard deviation of SA through IRT. Similarly, MLS had an indirect effect (0.02) on SA through IRT.

According to the total effect values between the variables, the exogenous variable CLEP caused a total change of 0.53 units on IRT and 0.07 units on SA and the exogenous variable MLS caused a total change of 0.17 units on IRT and 0.02 units on SA. Finally, IRT created a change of 0.14 units on SA. Based on the findings, the final model is provided in Figure 6.

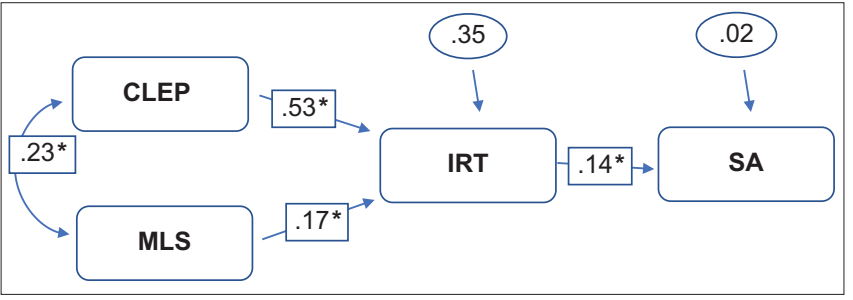

Figure 5: Path coefficients of the modified model $\left({ }^{*}<0.05\right)$

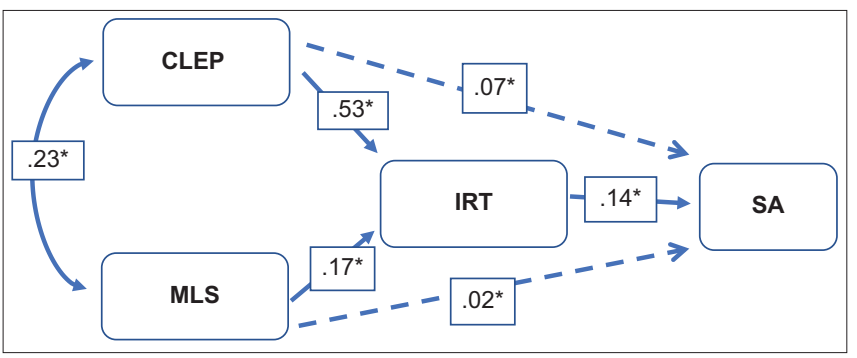

Figure 6: The final model (indirect effects shown with dotted lines)
Considering all findings, although the hypothesized model created based on the literature was not fully confirmed, it was largely supported by the data. The results of the path analysis revealed that students' CLEP positively affects their IRT behaviors in learning science and SA. A similar influence was observed for students' MLS. In addition, IRT behaviors predicted students' SA in science.

\section{DISCUSSIONS, CONCLUSION, AND RECOMMENDATIONS}

This study examined eight-grade gifted students' MLS, perceptions about learning environments, IRT behaviors, and academic achievement in science. The descriptive results revealed that the participants had above average SA in science, IRT level, CLEP, and intrinsic MLS. In addition, according to the path analysis results, while gifted students' CLEP and MLS predicted their IRT behaviors and SA in science, their IRT behaviors predicted their SA. The findings of this study on motivation supported the literature on the gifted students.

In the study, it was found that eight-grade gifted students had high intrinsic MLS. Intrinsic motivation is a critical element of creativity and persistent learning (Ryan and Stiller, 1991). Specifically, gifted students are highly motivated to complete a duty from the beginning to the end. Renzulli (1976) describes being gifted as having SA, creativity, and motivation above average. Similarly, Davaslıgil (2004) discusses advanced intellectual ability, special talents in various fields, sensitivity, creativity, and high motivation as characteristics that distinguish gifted students from their peers. According to the studies, gifted students are more motivated to learn compared with their peers (Davis and Rimm, 1989; Köksal, 2013a; Yang et al., 2014).

Another finding of the study is related to gifted students' CLEP. The participants considered the learning environment as full of constructive activities, where the responsibility was not only on the classroom teacher but also on the students and where active participation of all learners takes place. In a similar study, Rita and Martin-Dunlop (2011) found that while students prefer more constructive learning environment than their current learning environments, gifted students' perception about their current learning environments was more positive than the other students' perceptions. This finding may be related to the structure of science lessons. Science lessons require scientific

Table 8: Direct, indirect, and overall effect values

\begin{tabular}{|c|c|c|c|c|c|c|c|c|c|}
\hline \multirow[t]{3}{*}{ Variables } & \multicolumn{9}{|c|}{ Explanatory variables } \\
\hline & \multicolumn{3}{|c|}{ CLEP } & \multicolumn{3}{|c|}{ MLS } & \multicolumn{3}{|c|}{ IRT } \\
\hline & Direct & Indirect & Overall & Direct & Indirect & Overall & Direct & Indirect & Overall \\
\hline \multicolumn{10}{|c|}{ Explained Variable } \\
\hline IRT & 0.53 & & 0.53 & 0.17 & - & 0.17 & - & - & - \\
\hline SA & - & 0.07 & 0.07 & & 0.02 & 0.02 & 0.14 & - & 0.14 \\
\hline
\end{tabular}


process skills, engineering design skills, and life skills to be actively used in teaching processes (MONE, 2016). Gifted students have the potential to perform high-level abilities in science (Soares, 2016). In other words, gifted students can manage to complete many active learning activities from designing and conducting an experiment to designing artifacts to solve high-level problems. In the literature, there exist studies reporting that students with or without gifted diagnosis generally regard science learning environments as constructive learning environment (Eroğlu et al., 2015; Kim et al., 2000; Özkal et al., 2009). On the other hand, high-level motivation, which is included in the definition of giftedness (Renzulli, 1986), may trigger positive perceptions about learning environment. There is a high correlation between gifted students' CLEP and their motivation (Akkanat and Gökdere, 2018; Lüftenegger et al., 2015). In this study, the data were collected from gifted students registered to SAC. Since learning activities in SAC are based on project-based learning, problems solving, and learning by experimentation, which are the elements of constructive learning, students are exposed to constructive learning in these centers (MONE, 2016).

In the study, it was found that eight-grade gifted students' level of IRT behavior was above average. More specifically, gifted students tend to share their thoughts in science even though they are not sure about correctness of their thoughts, gain new knowledge even though they may make mistakes, and talk about their solutions even though other students' may have negative thoughts about themselves. Science courses require students to take intellectual risks. Actually, students have to uncover some information they do not know through experiments, discuss their thoughts related to a scientific problem without any concern, and ask questions and defend themselves about an association between the phenomena they observe and scientific concepts that they cannot make sense. According to Soares (2016), gifted students take intellectual risks by focusing on various solutions while solving a scientific problem and questioning the phenomenon related to the problem. National studies also reveal that gifted students' IRT levels are above average (Akdağ et al., 2016; Akdağ and Köksal, 2016). The emphasis on enrichment, challenge, and independent study in teaching in SAC may also be an important explanation for this situation (MONE, 2016).

Another critical finding of the study is that gifted students' SA levels were above average. A similar result was found in a study conducted by Ertekin (2017). This result may be related to gifted students' ability to employ various cognitive skills special to science including establishing association between the scientific concepts and observed phenomenon, understanding scientific models and theories, and creating patterns related to scientific data without unknown connections (Gilbert and Newberry, 2007). According to Gould et al. (2003), gifted students can understand scientific concepts in depth by knowing different facts in science compared to their peers. In short, it may be concluded that eight grade-gifted students are successful in science courses.
One of the inferential results of the study is that eight-grade gifted students' CLEP directly influenced their IRT behaviors and indirectly influence SA via IRT behaviors. In other words, the fact that gifted students consider science-learning environments as constructive learning environment positively affects their IRT behaviors. According to Byrnes (1998), IRT is a critical factor in active learning. More specifically, constructive learning environments are based on the idea that students may make mistakes; however, those mistakes should not be underestimated or should not be avoided (Jonassen et al., 1999). Furthermore, constructive learning environments require students to produce knowledge by themselves rather than getting it directly from instructors, which means that students need to reach knowledge by using the scientific process skills in science education. Students' production of knowledge is based on the principle of making an effort to reach information even they are not sure of the result. In the literature, there is no study directly examining the association between IRT behaviors and science-learning environments. Constructivist learning approach is related with problem-based learning, active learning, and cooperative teaching strategies (Wilson, 1996). Weingrad (1998) stated that students take intellectual risks in learning environments in which they use reasoning processes, which shed light on the relationship between IRT and constructive learning environments. In a similar study, Köksal and Köseoğlu (2019) put strong emphasis on conditions of taking intellectual risks. Çakır (2017) also revealed that students who were exposed to constructive learning environments showed more IRT behaviors compared with their peers who were exposed to traditional learning environments. In short, conducting science activities with gifted students in constructive environments will positively affect their IRT behavior.

There was no direct association between students' CLEP and their SA in science. However, some studies revealed positive effect of learning environment perceptions on SA in science for students with and without gifted diagnosis (Gautam, 2020; Ural and Bümen, 2016; Rita and Martin-Dunlop, 2011). On the other hand, Cairns and Areepattamannil (2017) found a negative effect of inquiry-based learning, which is based on constructivist approach, on students' SA in science. Furthermore, Cairns (2019) conducted a study using PISA 2015 dataset and found that students who constantly conduct science experiments had lower SA compared with students who occasionally conduct science experiments. According to these results, it may be concluded that CLEP does not always affect students' SA positively. On the other hand, in this study, it was found that students' perceptions indirectly influenced students' achievement through their IRT behaviors. In inquiry-based learning environments, students' freedom to ask questions and answer them is considered as a critical factor that increases the quality of teaching (Sadeh and Zion, 2009; Windschitl, 2002). For example, in the directed inquiry approach, teachers provide the problem to students and students have full responsibility to find out the solution (Windschitl, 
2002). Trautmann et al. (2004) state that the directed inquiry approach decreases students' sense of failure and their fear of not reaching a solution, which emphasizes the IRT behaviors' role on students' success in inquiry based learning. This may imply the indirect effect of learning environment perception on SA via IRT behavior. In short, if science activities for eight grade-gifted students are designed to encourage students' risk-taking behaviors, these activities are more likely to lead them to success.

One of the important findings of this study is related to students' intrinsic MLS. According to the findings, students' intrinsic motivation had direct and positive influence on students' IRT behaviors and indirect and positive influence on their SA in science through IRT behaviors. According to this result, gifted students who can use their internal motivation in a task-oriented manner and complete a goal-oriented activity as they wish are expected to be more resistant to the difficulties they may encounter during their learning process, be willing to participate in activities even if they fail, and easily reveal their potential. While Sak (2010) reported that motivation is a key factor for gifted students' SA, Karnes and Riley (2005) state that gifted students with high motivation toward science may carry out an experiment for a long time without being distracted even though they do not know the result. In addition, students with high interest in science are more willing to take intellectual risks and have the power to overcome failure, deterioration, and disappointments they may encounter (Hunter and Csikszentmihalyi, 2003). There is no study in the literature that directly examines students' intrinsic goal orientation, which is a dimension of motivation in the current study, and IRT behaviors. However, Beghetto (2009) examined students' IRT behaviors and creative self-efficacy, which is a sub-dimension of motivation according to Rogers et al. (1999), and found positive association. In addition, Öner Sünkür et al. (2013) focused on eight grade students' IRT behaviors and their positive and negative perfectionism, which is another factor of motivation. They found that positive perfectionism had a positive and significant effect on students' IRT behaviors. Positive perfectionism as an intrinsic motivation factor has the power to trigger one's willingness to learn (Kottman and Ashby, 2000; Stoeber and Otto, 2006). In this respect, the current study explains the association between intrinsic motivation and IRT.

In the current study, no direct association was found between students' intrinsic motivation and SA in science. Although some studies revealed the positive and high-level association between students' SA in science and motivation (Areepattamannil et al., 2011; Kingir et al., 2013; Pintrich and De Groot, 1990), there are other studies where this strong positive relationship was not observed. According to PISA 2015 National Report (OECD, 2016), although Turkish students had a SA below the OECD average in the PISA 2015 exam, their motivation and interest in learning science was quite high. Edwards (2019) examined gifted students' intrinsic motivation and SA in science in terms of gender. The results revealed that although female students' intrinsic MLS had a high correlation with their SA, the significance level of this association is quite low for male students. Furthermore, Yenice et al. (2012) found that middle school students' MLS decreases as their grade level increases. In this particular study, the participants consisted of eight-grade gifted students and the number of male students in the sample group was approximately twice as high as the number of female students. This limitation may be the reason for the insignificant association between motivation and SA. On the other hand, there was an indirect effect of motivation on SA through IRT behaviors, which implies that IRT is a motivational factor in science learning. Therefore, to increase eight-grade gifted students' MLS, their IRT behaviors must be taken into account.

Another critical finding of the current study is the association between IRT behaviors and SA. Students' IRT behaviors positively predicted their SA in science. This means that when gifted students are willing to answer questions even though they do not know the answer, design and conduct experiments even though they do not know the results, design new and original products without worrying about criticisms from their classmates, and share their thoughts about others' products and argumentations, their SA in science increases. This argumentation is supported by the other studies as well. Özbay (2016) examined the association among middle school students' SA in science, scientific epistemological beliefs, and IRT behaviors and found that IRT behaviors positively predicted students' SA. In another study, Çakır and Yaman (2015) investigated middle school students' IRT skills, metacognitive awareness, and SA and found a moderate level association between students' IRT skills and SA in science. Deveci and Aydin (2018) found similar results. In addition, Tay et al. (2009) examined gifted students' problem solving skills and IRT behaviors. They revealed that problem solving skills, which is critical for SA in science (Durgun and Önder, 2019), had a positive association with IRT behaviors.

Due to its nature, science is a field that contain scientific process skills including observations, hypothesis, and determining variables and conducting experiments. Undoubtedly, science has the power to develop countries' economy by providing technological innovations that facilitate human life and making important inventions with the effort to understand nature, people, and the universe. Due to their high-level thinking skills, gifted individuals are key people for the development of a country since they have the potential to undertake very important innovations and inventions in the field of science. Therefore, it is critical to determine the factors that affect those students' SA and the associations among those factors. In this context, this study aimed to examine eight grade-gifted students' MLS, perceptions about learning environment, IRT behaviors, and academic achievement through path analysis. The previous studies were conducted by recruiting participants other than gifted students and performing basic level analysis with a few variables. Compared to other studies, this study differs by using path analysis and considering the predictability of four variables on a model basis. The findings revealed 
positive associations among gifted students' MLS, IRT behaviors, constructivist learning environment perceptions, and academic achievement in science. More specifically, gifted students' MLS and CLEP directly affect their IRT behaviors and indirectly affect their SA. Based on the findings, it is concluded that eight-grade gifted students should be exposed to science learning environments in which they feel free to share their thoughts, active learning takes place, and activities that increase students' intrinsic motivation are employed. This may advance gifted students' IRT skills and, as a result, increase their SA in science. In the literature, there is no study that examines the explanatory relationships among gifted students' CLEP, MLS, IRT skills, and SA in science at the same time. In addition, this study provides data for meta-analysis studies and observation-based research in the future. Since the eighth grade is the grade level in which decreases are observed in students' motivation and attitude levels, the findings of this study also contribute to researchers focusing on the discussed problems. Moreover, the study also provides suggestions for effective and cognitive components that should be taken into account from the design of science activities carried out in SACs to the implementation and evaluation process.

\section{LIMITATIONS}

Considering the findings, limitations of the study, and difficulties encountered during the research, the following suggestions are offered. The first limitation is related to the variables. Although the ability to take intellectual risks for science learning is an important variable that affects SA, there may exist other affective and cognitive variables that may be related to this variable. In the future studies, it is critical to develop models that explain the association among those variables. The second limitation is that the participants of this study consisted of only eight grade-gifted students. The associations among the variables need to be examined for the other gifted students from different age groups and the students without gifted diagnosis. Another limitation is that this study was designed based on quantitative research method. Future research must be considering employing other data collection techniques, which are part of qualitative or mixed research method. The next limitation is related to motivation and its other dimensions. Intrinsic motivation was taken into account as a dimension in this particular study. Motivation for learning science includes many different dimensions such as internal control. More research is needed by considering other motivational factors as well. Another limitation is that a hypothetical model was created in order to examine the relationship among science learning environment perception, motivation for learning science, IRT, and academic achievement in science variables. In the future, experimental studies may be conducted on the effects of the mentioned variables on IRT behaviors and SA. Finally, in the study, a direct relationship was not found between the intrinsic motivation toward science and the science learning environment perception variables and the SA in science variable. Therefore, this study must be replicated with a larger sample group.

\section{REFERENCES}

Akdağ, E, Köksal, M., \& Ertekin, P. (2016). Üstün yetenekli ortaokul öğrencilerinin fen öğrenmede zihinsel risk alma davranışlarının sinif düzeyi ve cinsiyet değişkenleri açısından incelenmesi [Investigating gifted middle school students' intellectual risk taking behaviors in learning science across gender and grade]. Adnan Menderes University Social Sciences Institute Journal, 4(2), 16-25.

Akdağ, E., \& Köksal, M. (2017). Üstün yetenekli ortaokul öğrencilerinin fen bilimlerini öğrenmede zihinsel risk alma davranışları açısından akranlarıyla karşlaştırılması [Comparison of middle school gifted students with their peers in terms of intellectual risk taking levels regarding learning science]. Primary Education Online, 16(4), 16441651.

Akkanat, Ç., \& Gökdere, M. (2018). The effect of academic involvement and school climate as perceived by gifted students in terms of talent, creativity, and motivation in science. Universal Journal of Educational Research, 6(6), 1167-1174.

Akkaya, G. (2016). Rol Model Içerikli Animasyonların Üstün Yetenekli 4. Sınıf Öğrencilerinin fen Bilimleri Dersinde Zihinsel Risk Alma Davranışlarl ve Ögrenmelerine Etkisi [The Effect of Animations Involving Models on Fourth Grade Gifted Students' Intellectual Risk Taking and Learning in Science Courses]. (Thesis Number: 436952) [Master Thesis, İnönü University. Council of Higher Education Thesis Center).

Alkan, İ., \& Bayri, N. (2017). Fen öğrenmeye yönelik motivasyon ile fen başarısı arasındaki ilişki üzerine bir meta analiz çalışması [A metaanalysis study on the relationship between motivation for science learning and science achievement]. Dicle University, Ziya Gökalp Education Faculty Journal, 32, 865-874.

Areepattamannil, S., Freeman, J.G., \& Klinger, D.A. (2011). Influence of motivation, self-beliefs, and instructional practices on science achievement of adolescents in Canada. Social Psychology of Education, 14(2), 233-259.

Asher, H.B. (1983). Causal Modelling. New York: Sage Publications.

Aşut, N. (2013). Üstün Yetenekli Öğrencilerin Epistemolojik Inançlarının fen Öğrenmeye Yönelik Motivasyon Düzeyi ve fen Başarısılla Ilişkisi [Relationship of Gifted Students'Epistemological Beliefs with Science Achievement and Motivation towards Science Learning] (Thesis Number: 350922) [Master Thesis, İnönü University. Council of Higher Education Thesis Center).

Baş, G. (2012). İlköğretim öğrencilerinin yapılandırmacı öğrenme ortamına ilişkin algılarının farklı değişkenler açısından değerlendirilmesi. [Evaluation of elementary students' views on constructivist learning environment with respect to various variables]. Journal of Research in Education and Teaching, 1(4), 203-215.

Baumgartner, H., \& Homburg, C. (1996). Applications of structural equation modeling in marketing and consumer research: A review. International Journal of Research in Marketing, 13(2), 139-161.

Bayram, N. (2013). Yapısal Eşitlik Modellemesine Giriş: AMOS Uygulamalarl [Introduction to Structural Equation Modelling: AMOS Applications]. $2^{\text {nd }}$ ed. New York: Ezgi Publishing.

Beghetto, R.A. (2009). Correlates of intellectual risk taking in elementary school science. Journal of Research in Science Teaching, 46(2), 210-223.

Bentler, P.M., \& Yuan, K.H. (1999). Structural equation modeling with small samples: Test statistics. Multivariate Behavioral Research, 34(2), 181-197.

Büyüköztürk, Ş., Akgün, Ö.E., Demirel, F., \& Özkahveci, Ö. (2004). Güdülenme ve öğrenme stratejileri ölçeği'nin türkçe formunun geçerlik ve güvenirlik çalışması [The validity and reliability study of the Turkish version of the motivated strategies for learning questionnaire]. Educational Sciences: Theory and Practice, 4(2), 207-239.

Büyüköztürk, Ş., Çakmak, E, Akgün, Ö., Karadeniz, Ş., \& Demirel, F. (2016). Bilimsel Araştırma Yöntemleri [Scientific Research Methods] Pegem Akademi.

Byrne, B.M. (2010). Structural Equation Modeling with AMOS: Basic 
Concepts, Applications, and Programming. $2^{\text {nd }}$ ed. Milton Park, Abingdon-on-Thames: Routledge.

Byrnes, J.P. (1998). The Nature and Development of Decision Making: A Self-regulation Model. Mahwah, NJ: Lawrence Erlbaum Associates Publishers.

Cairns, D. (2019). Investigating the relationship between instructional practices and scienceachievement in an inquiry-based learning environment. International Journal of Humanities and Social Science, 41(15), 2113-2135.

Cairns, D., \& Areepattamannil, S. (2017). Exploring the relations of inquirybased teaching to science achievement and dispositions in 54 countries. Research in Science Education, 49, 1-23.

Çakır, E. (2017). Ters Yüz Sinif Uygulamalarinin fen Bilimleri 7. Sinif Ögrencilerinin Akademikbaşari, Zihinsel Risk Alma ve Bilgisayarca Düşünme Becerileri Üzerine Etkisi [The Effect of Flipped Classroom on $7^{\text {th }}$ Grade Students' Academic Achievement, Cognitive Risk Taking Skills and Computational Thinking Skills in Science Education Classroom]. (Thesis Number: 456600) (Master Thesis, Ondokuz Mayis University. Council of Higher Education Thesis Center).

Çakır, E., \& Yaman, S. (2015). Ortaokul öğrencilerinin zihinsel risk alma becerileri ve üst bilişsel farkındalıkları ile akademik başarıları arasındaki ilişki [The relationship between students' intellectual risktaking skills with metacognitive awareness and academic achievement]. Gazi Journal of Educational Sciences, 1(2), 163-178.

Çokluk, O., Şekercioglu, G., \& Büyüköztürk, Ș. (2012). Multivariate Statistics for the Social Sciences: SPSS and LISREL Applications. Ankara: Pegem Academy Publishing.

Daşc1, A.D., \& Yaman, S. (2014). Investigation of intellectual risktaking abilities of students according to Piaget's stages of cognitive development and education grade. Journal of Theoretical Educational Science, 7(3), 271-285.

Daşdağ, M.M., Çelik, M.Y., Satıcı, Ö., Akkuş, Z., \& Çelik, H.C. (2006). Hangi tür araștırmalarda path analizi kullanılmalıdır [Which kind of research should use Path analysis?]. Dicle Üniversitesi Tip Fakültesi Biyoistatistik Anabilim Dall, IX Ulusal Biyoistatistik Kongresi. Diyarbakır, Turkey: Dicle University Medicine Faculty Biostatistics Section, IX. National Biostatistics Congress.

Davaslıgil, Ü. (2004). Üstün Çocuklar [Gifted Children]. In: Şirin, R., Kulaksızoğlu, A., \& Bilgili, A.E., (Eds.), Üstün Yetenekli Çocuklar: Seçilmis Makaleler Kitabı. [Gifted Children: Selected Articles Book]. Çocuk Vakfi Yayınları. New York: Children Foundation Publications. pp. 211-218.

Davis, G.A., \& Rimm, S.B. (1989). Education of the Gifted and Talented. Hoboken, New Jersey: Prentice-Hall.

Davis, G.A., \& Rimm, S.B. (2004). Education of the Gifted and Talented. $5^{\text {th }}$ ed. Needham, Massachusetts: Needham Heights.

Deveci, İ., \& Aydin, F. (2018). Relationship between students' tendencies toward academic risk-taking and their attitudes to science. Issues in Educational Research, 28(3), 560-577.

Durgun, E., \& Önder, İ. (2019). Ortaokul 7. sinif öğrencilerinin fen bilimleri başarilari ile okuduğunu anlama, grafik okuma ve problem çözme becerileri arasindaki ilişki [The relationship between the science achievement of secondary school seventh grade students and reading comprehension, graph reading, problem solving skills]. Journal of Individual Differences in Education, 1(1), 1-13.

Edwards, T.A. (2019). Identifying the Impact of Intrinsic Motivation on Female Middle school Science Achievement. Arizona: Grand Canyon University Phoenix.

Eroğlu, S., Armağan, F., \& Bektaş, O. (2015). Fen bilimleri dersi öğrenme ortamlarinin yapilandirmaci özellikler açisindan değerlendirilmesi [Evaluation of learning environment of science course in terms of constructivist properties]. Ahi Evran University Kirsehir Education Faculty Journal, 2, 293-312.

Ertekin, P. (2017). Üstün Yetenekli Ortaokul Öğrencilerinin Uzamsal akil Yürütme Becerilerinin Astronomi Konularina Yönelik Kavramsal Anlayișlari ve Akademik Bașarilari ile Ilișkisinin Incelenmesi [Investigating the Relatıonshıp of Middle School Gifted Students' Spatial Reasoning Skills with their Conceptual Understaning of Astronomy Subjects and Academic Achievement] (Thesis Number: 495704) (Master Thesis, İnönü University. Council of Higher Education of Thesis Center).

Esin, N. (2014). Veri toplama yöntem ve araçları, veri toplama araçlarının güvenirlik ve geçerliği [Data collection methods and tools, validity and reliability of data collection tools]. In: Erdoğan, S., Nahcivan, N., \& Esin, M., (Eds.), Hemşirelikte Araştırma, Süreç, Uygulama ve Kritik [Research, Processes, Applications and Critics in Nursing]. Mumbai, Maharashtra: Nobel Publishing. pp. 78-98.

Gautam, A. (2020). Effectiveness of 5 E instructional model in terms of science achievement at secondary level. Studies in Indian Place Names, 40(71), 1228-1238.

Gilbert, J.K., \& Newberry, M. (2007). The characteristics of the gifted and exceptionally able in science. In: Taber, K.S., (Ed.), Science Education for Gifted Learners. Milton Park, Abingdon-on-Thames: Routledge. pp. 15-31.

Glynn, S., Aultman, L., \& Owens, A. (2005). Motivation of learn in general education programs. Journal of General Education, 54(2), 150-170.

Gould, C.J., Weeks, V., \& Evans, S. (2003). Science starts early. Gifted Child Today Magazine, 26, 38-43.

Guay, F., Chanal, J., Ratelle, C.F., Marsh, H.W., Larose, S., \& Boivin, M. (2010). Intrinsic, identified, and controlled types of motivation for school subjects in young elementary school children. British Journal of Educational Psychology, 80(4), 711-735.

Hoh, P.S. (2008). Cognitive characteristics of the gifted. In: Plucker, J.A., \& Callahan, C.M., (Eds.), Critical Issues and Practices in Gifted Education: What the Research Says. Texas, United States: Prufrock Press. pp. 57-83.

House, D.J. (2002). Investigation of the Effects of Gender and Academic Selfefficacy on Academic Risk-taking for Adolescent Students. (Doctoral Dissertation, Oklahoma State University).

Hunter, J.P., \& Csikszentmihalyi, M. (2003). The positive psychology of interested adolescents. Journal of Youth and Adolescence, 32, 27-35.

İlhan, M., \& Çetin, B. (2014). LISREL ve AMOS programları kullanılarak gerçekleştirilenyapısal eşitlik modeli (YEM) analizlerine ilişkin sonuçların karşılaştırılması [Comparing the analysis results of the structural equation models (SEM) conducted using LISREL and AMOS]. Eğitimde ve Psikolojide Ölçme ve Değerlendirme Dergisi, [Journal of Measurement and Evaluation in Education and Psychology], $5(2), 26-42$.

Johnson, B., \& McClure, R. (2004). Validity and reliability of a shortened, revised version of the constructivist learning environment survey (CLES). Learning Environments Research, 7, 65-80.

Jonassen, D.H., Peck, K.L., \& Wilson, B.G. (1999). Learning with Technology: A Constructivist Perspective. Hoboken, New Jersey: Merrill/Prentice-Hall.

Kanlı, E., \& Emir, S. (2009). Fen ve teknoloji öğretiminde probleme dayalı öğrenmenin üstün zekâlı ve normal öğrencilerin motivasyon düzeylerine etkisi [The effect of problem based learning in science and technology to the motivation levels of gifted and normal students]. Sakarya University Education Faculty Journal, 18, 42-61

Karnes, F.A., \& Riley, T.L. (2005). Competitions for Talented Kids. Texas, United States: Prufrock Press.

Kim, H., Fisher, D., \& Fraser, B. (2000). Classroom environment and teacher interpersonal behaviour in secondary science classes in Korea. Evaluation and Research in Education, 14, 3-22.

Kıngır, S., Taş, Y., Gök, G., \& Vural, S.S. (2013). Relationships among constructivist learning environment perceptions, motivational beliefs, self-regulation and science achievement. Research in Science \& Technological Education, 31(3), 205-226.

Kline R. (2011). Principles and Practice of Structural Equation Modeling. New York: Guilford Press.

Köksal, M.S. (2013a). Comparison of gifted and advanced students on motivation toward science learning and attitude toward science. Journal of the American Academy of Special Education Professionals, 1, 146-158.

Köksal, M.S. (2013b). Investigation of higher-order correlates of gifted students' motivation towards science learning. GESJ: Education Sciences and Psychology, 6(32), 18-26.

Köksal, M.S., \& Köseoğlu, P. (2019). Teknolojiyi öğrenirken zihinsel risk alınması: Fen bilgisi öğretmen adayları örneği [Intellectual risk taking when learning about technology: Case of prospective science teachers] 
Gazi Journal of Education Faculty, 39(1), 37-61.

Kottman, T., \& Ashby, J. (2000). Perfectionistic children and adolescents: Implications for school counselors. ASCA, Professional School Counseling, 3, 183-189.

Lang, Q.C., Wong, A.F.L., \& Fraser, B.J. (2005). Student perceptions of chemistry laboratory learning environments, student-teacher interactions and attitudes in secondary school gifted education classes in Singapore. Research in Science Education, 35, 299-321.

Lee, O., \& Brophy, J. (1996). Motivational patterns observed in sixth-grade science classrooms. Journal of Research in Science Teaching, 33(3), 585-610.

Lüftenegger, M., Kollmayer, M., Bergsmann, E., Jöstl, G., Spiel, C., \& Schober, B. (2015). Mathematically gifted students and high achievement: The role of motivation and classroom structure. High Ability Studies, 26(2), 227-243.

Mardia, K.V. (1970). Measures of multivariate skewness and kurtosis with applications. Biometrika, 57(3), 519-530.

Marlowe, B.A., \& Page, M.L. (2005). Creating and Sustaining the Constructivist Classroom. Thousand Oaks, CA: Corwin.

Martin, A.J. (2001). The student motivation scale: A tool for measuring and enhancing motivation. Australian Journal of Guidance and Counselling, $11,11-20$.

Matthews, M.S., \& McBee, M. (2007). School factors and the underachievement of gifted students in a talent search summer program. Gifted Child Quarterly, 51, 167-181.

Meyers, L.S., Gamst, G., \& Guarino, A.J. (2016). Applied Multivariate Research: Design and Interpretation. Thousand Oaks: Sage Publications.

MONE. (2016). T.C. Milli Eğitim Bakanlı̆̆ Bilim ve Sanat Merkezi Yönergesi [Regulation Document for Science and Art Centers]. Turkey: Ministry of National Education, Turkey.

MONE. (2017). İlköğretim ve Ortaögretim Öğretim Programlarının Güncellenmesi [Update of Elementary and Secondary School Instructional Programs]. Turkey: Ministry of National Education, Turkey.

Morris, J., Slater, E., Fitzgerald, M.T., Lummis, G.W., \& van Etten, E. (2019). Using local rural knowledge to enhance STEM learning for gifted and talented students in Australia. Research in Science Education, 51, 61-79.

Neihart, M. (1999). Impact of giftedness on psychological well-being. Roeper Review, 22(1), 123-127.

Nickerson, R.S. (1999). Enhancing creativity. In: Sternbeg, R.J., (Ed.), Handbook of Human Creativity. Cambridge, United Kingdom: Cambridge University Press. pp. 392-430.

OECD. (2016). PISA 2015 Assessment and Analytical Framework: Science, Reading, Mathematic and Financial Literacy. Paris, France: PISA, OECD Publishing.

Olobatuyi, M.E. (1992). A User's Guide to Path Analysis. Lanham, Maryland: University Press of America.

Özbay, E.H. (2016). Ortaokul Öğrencilerinin Akademik Başarılarının Bilimsel Epistemolojik Inançlar ve Zihinsel Risk Alma Davranışları ile Ilişkisinin Incelenmesi [Investigation of Association among Scientific Epistemological Beliefs, Intellectual Risk Taking and Science Achievement of Middle School Students] (Tez Numaras1:436956) (Master Thesis, Inonu University. Council of Higher Education of Thesis Center).

Özkal, K., Tekkaya, C., \& Cakiroglu, J. (2009). Investigating $8^{\text {th }}$ grade students' perceptions of constructivist science learning environment. Education and Science, 34(153), 38-46.

Pedhazur, E.J. (1997). Multiple Regression in Behavioral Research: Explanation and Prediction. New York: Holt, Rinehart and Winston.

Pehlivan Tunç, E.B., \& Kutlu, Ö. (2014). Investigation of answering behaviour in Turkish test. Journal of Measurement and Evaluation in Education and Psychology, 5(1), 61-71.

Pintrich, P.R. (2003). A motivational science perspective on the role of student motivation in learning and teaching contexts. Journal of Educational Psychology, 95(4), 667.

Pintrich, P.R., \& De Groot, E.V. (1990). Motivational and self-regulated learning components of classroom academic performance. Journal of Educational Psychology, 82, 33-40.

Pintrich, P.R., Smith, D.A.F., Garcia, T., \& McKeachie, W.J. (1991). A Manual for the Use of the Motivational Strategies Learning
Questionnaire (MSLQ). National Center for Research to Improve Postsecondary Teaching and Learning.

Pramathevan, G.S., \& Fraser, B.J. (2019). Learning environments associated with technology-based science classrooms for gifted Singaporean females. Learning Environments Research, 23, 195-215.

Rainwater, C., \& Wittner, N. (2016). Developing a rebel with a cause through creative risk-taking in gifted students. In: Interplay of Creativity and Giftedness in Science. Paderborn: Brill Sense. pp. 381-398.

Renzulli, J.S. (1976). The enrichment triad model: A guide for developing defensible programs for the gifted and talented. Gifted Child Quarterly, 20(3), 303-306.

Renzulli, J.S. (1986). The Tree Ring Conception of Giftedness: A Developmental Model for Creative Productivity Conception of Giftedness. Cambridge: Press Syndicate of University of Cambridge.

Rita, R., \& Martin-Dunlop, C. (2011). Perceptions of the learning environment and associations with cognitive achievement among gifted biology students. Learning Environments Research, 14, 25-38.

Robinson, L.E., \& Bell, A. (2012). Exploring Adult Risk Propensity and Academic Risk-Taking within the Online Learning Environment. Saratoga, Springs: Paper Presented at the Adult Education Research Conference (AERC).

Rogers, S., Ludington, J., \& Graham, S. (1999). Motivation and Learning: A Teacher's Guide to Building Excitement for Learning and Igniting the Drive for Quality. Colorado: Peak Learning Systems.

Ryan, R.M., \& Stiller, J. (1991). The social contexts of internalization: Parent and teacher influences on autonomy, motivation and learning. Advances in Motivation and Achievement, 7, 115-149.

Sadeh, I., \& Zion, M. (2009). The development of dynamic inquiry performances within an open inquiry setting: A comparison to guided inquiry setting. Journal of Research in Science Teaching, 46(10), $1137-1160$.

Sak, U. (2010). Üstün Zekâlılar: Özellikleri Tanılanmaları Eğitimleri [Gifted Individuals: Characteristics, Identification and Education]. Istanbul, Turkey: Maya Akademi.

Schermelleh-Engel, K., \& Moosbrugger, H. (2003). Evaluating the fit of structural equation models: Tests of significance and descriptive goodness-of-fit measures. Methods of Psychological Research Online, $8(2), 23-74$

Schulze, S., \& Lemmer, E. (2017). Family experiences, the motivation for science learning and science achievement of different learner groups. South African Journal of Education, 37(1), 1-9.

Schumacker, R.E., \& Lomax, R.G. (2010). A Beginner's Guide to Structural Equation Modeling. Milton Park, Abingdon-on-Thames: Routledge.

Soares, L. (2016). Sciencing: creative, scientific learning in the constructivist classroom. In: Demetrikopoulos, M.K., \& Pecore, J.L., (Eds.), Interplay of Creativity and Giftedness in Science. Berlin: Springer. pp. 127-151.

Stoeber, J., \& Otto, K. (2006). Positive conceptions of perfectionism: Approaches, evidence, challenges. Personality and Social Psychology Review, 10, 295-319.

Suhr, D. (2008). Step your way through Path Analysis. Western Users of SAS Software Conference Proceedings. pp.1-10.

Sungur, S. (2004). In Implementation of Problem Based Learning in High School Biology Courses. Ankara: Unpublished Doctoral Dissertation, ODTÜ, Ankara.

Sünkür, M.O., İlhan, M., Kinay, İ., \& K1lınç, M. (2013). An examination of the relation between $8^{\text {th }}$ grade students' level of academic risk taking and their positive and negative perfectionism traits. Çukurova University Faculty of Education Journal, 42(2), 1-10.

Tabachnick, B.G., \& Fidell, L.S. (2013). Using Multivariate Statistics. $6^{\text {th }}$ ed. London, United Kingdom: Pearson.

Tay, B., Özkan, D., \& Tay, B.A. (2009) The effect of academic risk taking levels on the problem solving ability of gifted students. Procedia Social and Behavioral Sciences, 1, 1099-1104.

Taylor, P.C., \& Fraser, B.J. (1991). Development of an Instrument for Assessing Constructivist Learning Environments. Wisconsin: The National Association for Research in Science Teaching (NARST).

Tomlinson, S. (2005). Education in a Post Welfare Society. New York: McGraw-Hill Education.

Trautmann, N., MaKinster, J., \& Avery, L. (2004). What makes inquiry so hard? (and why is it worth it?). In: Annual Meeting of the National 
Association for Research in Science Teaching. Toronto, Canada: Canada University Press.

Ural, G., \& Bumen, N. (2016). A meta-analysis on instructional applications of constructivism in science and technology teaching: A sample of Turkey. Education and Science, 41(185), 51-82.

Velayutham, S., Aldridge, J.M., \& Fraser, B. (2012). Gender differences in student motivation and self-regulation in science learning: A multigroup structural equation modeling analysis. International Journal of Science and Mathematics Education, 10, 1347-1368.

Watters, J.J., \& Diezmann, C.M. (2003). The Gifted students in science: Fulfilling potential. Australian Science Teachers Journal, 49(3), 46-53.

Weingrad, P. (1998). Teaching and learning politeness for mathematical argument in school. In: Lampert, M., \& Blunk, M.L., (Eds.), Talking Mathematics in School: Studies of Teaching and Learning. Cambridge, United Kingdom: Cambridge University Press. pp. 213-237.

Wilson, B.G. (1996). Constructivist Learning Environments: Case Studies in Instructional Design. Englewood Cliffs, NJ: Educational Technology Publications.
Windschitl, M. (2002). Framing constructivism in practice as the negotiation of dilemmas: An analysis of the conceptual, pedagogical, cultural, and political challenges facing teachers. Review of Educational Research, 72(2), 131-175.

Yaman, S., \& Köksal, M.S. (2014). Adapting Turkish form of intellectual risk-taking and perceptions about its predictors scale in science education: The validity and reliability study. Journal of Turkish Science Education, 11(3), 119-142.

Yang, I., Lee, S., Kim, S., \& Lim, S. (2014). Comparison of motivation system of science learning between gifted students and non-gifted students in elementary school. International Information Institute (Tokyo), 17(12), 6189-6194.

Yenice, N., Saydam, G., \& Telli, S. (2012). Determining factors affecting on primary school students' motivation towards science learning. Ahi Evran University Kırsehir Education Faculty Journal, 13(2), 231-247.

Yılmaz, H., \& Cavas, P.H. (2007). Reliability and validity study of the students' motivation toward science learning (SMTSL) questionnaire. Elementary Education Online, 6(3), 430-440. 